Mirosława Buchholtz*

\section{Enter al-Annuri}

DOI: http://dx.doi.org/1 0.12775/LC.2019.016

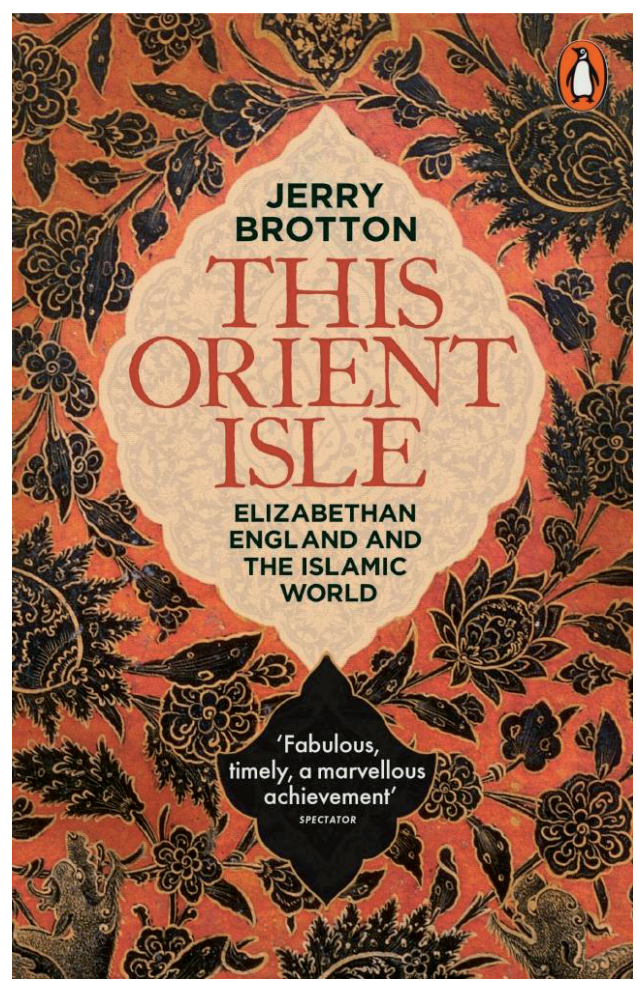

erry Brotton loves maps ${ }^{1}$ and large panoramas of the Renaissance, especially

* Prof. dr hab. nauk humanistycznych w zakresie literaturoznawstwa, kierownik Katedry Filologii Angielskiej na Wydziale Filologicznym Uniwersytetu Mikołaja Kopernika w Toruniu.

E-mail: Mirosława.Buchholtz@umk.pl.

1 He is also the author of Great Maps: The World's Masterpieces Explored and Explained. London: Dorling Kindersley, 2014 and A History of the World in 12 Maps. New York: Viking Adult, 2012. the English Renaissance ${ }^{2}$. Rephrasing "this sceptred isle” from Shakespeare's Richard II as "this Orient isle" in the title of his book on Elizabethan England and the Islamic World, Brotton sets out to unveil secrets hidden in plain sight. His overarching argument is that Elizabethan England was closer to the Arab world than has ever been admitted. The evidence has survived in historical documents, objects of material culture, and especially Elizabethan plays. Theatres thrived under Queen Elizabeth I and, as Brotton cogently argues, served as sensitive seismographs, offering commentary on current political events. Brotton repeatedly poses the question of how much playwrights may have known about the ostensible and secret missions of the politicians and travelers who were coming and going. They apparently knew a great deal, and perhaps sensed still more. The juxtaposition of their knowledge and understanding with the expertise of today's historian of culture in Brotton's book is indeed fascinating.

Brotton wants his readers to see, in the literal sense, and then also to grasp, to understand. The book abounds in images: the endpapers depict prospects of Constantinople, whereas a few illustrations in the text and over twenty colour plates show people, places and objects. In his text, Brotton sets images in motion, giving his book the flair of drama: a clear plotline, complete with monologues, epistolary dialogues, asides and an epilogue. Occasionally Brotton's book turns into a detective story or a political thriller. It opens with a vivid scene of the arrival of a forty-two-year-old Moroccan envoy to the court of Queen Elizabeth I towards the end of 1600. Enter al-Annuri. The narrator's repeated remarks about the envoy's percep-

2 See his Renaissance: A Very Short Introduction. Oxford [England], New York: Oxford University Press, 2005 and The Sultan and the Queen. New York: Viking, 2016. 
tion of the aging queen and her blackened teeth (she loved Moroccan sugar too much) are admittedly heavy-handed. The queen was no longer of marriageable age and the "marriage" proposal she received on that occasion was not personal. The business seemed quite fantastic, but it was nevertheless given due consideration by the queen and her trusted advisers. Al-Annuri's mission was supposedly to conclude an alliance between "English Protestants and Moroccan Muslims against their common enemy: Catholic Spain” (Brotton 2016: 1). However, the Anglo-Moroccan military alliance was to be aimed not only against Spain and its colonies in the Americas, but also against the Ottomans, which entailed an unprecedented prospect of English Christians and Moroccan Muslims uniting in order to overcome their respective Christian and Muslim opponents (6).

Brotton begins by outlining the apogee of Anglo-Muslim relations at the turn of the $16^{\text {th }}$ and $17^{\text {th }}$ centuries, and in the following ten chapters he retraces the stepping stones leading to that point. In an attempt to answer the question of "how Elizabethan England had become so close in its diplomatic, commercial and military policies to the Moroccan Sa'adian dynasty and many other Muslim powers" (7), he points to the Tudor monarchs' fascination with the Islam world evident, for example, in both business connections and clothing of Henry VIII. The king's only son and successor Edward VI did not live long enough to develop a foreign policy of his own. Edward's half-sister Mary I made a failed attempt to reinstate Catholicism and fortify the alliance with Spain, envisioning the defeat of infidels: Lutherans and "Turks" alike (Chapter 2 of Brotton's book).

Elizabeth I's excommunication from the Roman Catholic Church by Pope Pius $\mathrm{V}$ in 1570 encouraged the isolated queen to seek alliances beyond the Christian world. The painful shift from Catholicism to Protestantism made another shift from Protestantism to Islam if not immediately possible then at least imaginable, especially in the context of the Ottoman Empire's fame as "the world's most powerful and successful military machine” (14). Brotton's argument goes against the grain of the British self-aggrandizing myths, showing that the Elizabethans were "peripheral players on the margins of a geopolitical world dominated by the empires of Spain, Persia and the Ottomans" (16). Using this broad geopolitical tapestry as a background, Brotton weaves in stories of forgotten travelers, envoys, spies and tradesmen who penetrated the Arab world in the name of the Queen or on their own behalf. Anthony Jenkinson was one of the mid- $16^{\text {th }}$ century travelers who in the course of thirty years achieved more than any other Turdor adventurer: he met three of Asia's most powerful rulers, opened up trade with Russia, and gained unprecedented insights into the Islamic world (59).

In Elizabethan England's form of realpolitik, the line between trade and politics remained conveniently blurred (88). Trade came first, but political connections followed closely. Chapter 4 of Brotton's book brings the story of William Harborne, an English merchant who in 1582 became the English ambassador in Constantinople (88). This is a dramatic story of exceptional efforts, sudden setbacks, succcess, defeat and spectacular success again. By the late 1580s hundreds, possibly even thousands, of Elizabethan merchants, diplomats and artisans were active in the Islamic world (136). Some of them embraced Islam: by force, for strategic reasons or even willingly (140). Brotton's rich tapestry features such unlikely hero(in)es as the entrepreneurial aristocrat Bess of Hardwick (211-212) and the organist Thomas Dallam (228-230). 
Sir Anthony Sherley was far better known to his contemporaries than he is today. $\mathrm{He}$ became so (in)famous as an Oriental adventurer, a "bombastic, swaggering, slightly ridiculous nobleman" (265) that Shakespeare could use his name in The Twelfth Night and be sure that his audience would recognize the allusion (233). Sir Anthony seemed to epitomize English travelers to the Orient, who left England "in the hope of riches and preferment at the hands of various Muslim rulers, but ended up disillusioned and displaced, a stranger in a strange land, with little sense any more of where home was" (265).

A large part of Brotton's book is in fact devoted to the readings of "Islamic characters, themes or settings" in over sixty Elizabethan and Jacobean plays (12) performed in London's public theatres between 1576 and 1603 (176). While politicians sooner or later had to take sides, dramatists, and especially Shakespeare, could show ambivalent attitudes to "the Turks" (15). As England was developing difficult trade relations in both Morocco and Turkey in the 1580 s and 90s, the new theatre became an outlet for the Elizabethans' growing interest in the Arab world. Brotton mentions Robert Wilson's plays (110-111) and dismisses them as "clumsy melodrama" indebted to medieval morality plays (114). Wilson's topical allusions to usury (and Jewish brokers) and to the "corrupting influence of international trade in the Ottoman-controlled Mediterranean" (114) seem, however, quite relevant. In the 1580s the Elizabethan fascination with Islamic history finds its best example in Christopher Marlowe's Tamburlaine, which, as Brotton argues, neither celebrates nor condemns England's political alliance with the Islamic world (165). The success of Marlowe's play encouraged many other authors, including Thomas Kydd, George Peele or Robert Greene.
Whereas Thomas Nashe exemplified the fusion of Islamic and Catholic symbols (e.g. Mahomet's dove) in Protestant plays (185), Shakespeare complicated the image of the ethnically different. In Chapter 8, Brotton studies Titus Andronicus and The Merchant of Venice, proving that the insightful dramatist saw the ethnic variety where his contemporaries conflated (and were eager to expel both) Muslims and Jews (204). In the final Chapter 11 of Brotton's book, history and drama are happily united. The Moroccan envoy al-Annuri reappears as a mysterious hybrid figure of both history and Shakespeare's play. The dramatist may have actually met al-Annuri (287) and, as Brotton argues, may have been inspired by him to create the figure of Othello (12), who "embodies so much of Elizabethan England's contradictory relations with the Islamic world" (295). Repeatedly paying homage to Shakespeare's intellectual power and humanistic openness, Brotton refers also to his later plays. The scene of the play Thomas More (c. 1603-1604) which is believed to have been written by Shakespeare features a plea for tolerance and against xenophobic outbursts, such as May Day riots of 1517 (300-301). The Tempest (c. 1611) is, as Brotton argues, "a fitting conclusion to the history of Elizabethan England's relations with the Islamic world" (303). The Jacobean plays subverted that tradition, exemplifying a different attitude to the Arab world: they focused on history and employed a comical tone (304).

Both trade with and travel to the Islam world had an impact on the way Elizabethans of different social strata lived, dressed, ate and decorated their homes. But was a genuine understanding of Islam as a system of belief at all possible? The words "Muslim" and "Islam" entered the English vocabulary as late as 1615 and 1625 , respectively (9). The preferred word for the 
Arab people in Elizabethan England was "Turks" (25), irrespective of where exactly they came from. Brotton admits that Arabs provoked in Elizabethans a wide variety of emotions "from horror and disgust to wonder and curiosity" (9). There is no denying that the political and commercial relationship had its source not in "natural amity and tolerance", but in "expediency and realpolitik" (9). The latter concept reappears several times throughout Brotton's book, indicating that far from seeking to establish a lasting alliance, the English monarch sought timely solutions to political challenges arising in the world of dynamic change. This is perhaps the reason why it was so easy for Elizabeth I's successor, James I in the $17^{\text {th }}$ century to forget all about the Arab connection (297) and for the Georgian scholar Samuel Johnson in the $18^{\text {th }}$ century to dismiss "the Turks" as an unworthy subject of scholarly pursuits (10). Exit al-Annuri.

In the wake of the successful trade built up and conducted by Barbary Company, Turkey Company, Venice Company, and then Levant Company, the popular interest in the Muslim world surged towards the end of the $16^{\text {th }}$ century. At least sixty books, perhaps many more, were published on the subjects relating to the Ottomans (208). History of the Turks (1603) by Richard Knolles (printed by Adam Islip) was the first such history published in English. It was still known and read two hundred years later, most notably (and fruitfully) by Lord Byron. The first professorships in Arabic were established at Cambridge University in 1632 and four years later in Oxford. It is a paradox that political disengagement from the Islamic world in the Jacobean era coincided with the scholarly development in this area. Theoretical pursuits replaced a direct personal contact, while academic interest contained and circumscribed the Islamic world within intellectual frameworks of its own device. Thus, as Brotton bitterly remarks, "the Orient isle of Elizabethan England" turned into "an island of orientalism" (305). Imitating Prospero at the end of The Tempest, in the epilogue to his book, Brotton breaks down the boundaries of academic writing to recall in the final sentences of the book his own experience of growing up in a multicultural community. It is quite clear, not only at this point, but many times throughout his book, that his scholarly effort was guided by today's concern about the tense relations between people of different ethnic and religious identities.

Brotton seeks to prove that Islam, though so poorly understood by the English, perhaps with the exception of Marlowe and Shakespeare, is part of the national story of England (305). He seems to believe that it is his idea, and quite apart from the tradition of romantic Orientalism, which he only briefly mentions. Conspicuous by its absence in Brotton's book, however, is Virginia Woolf's fantastic biography of Orlando which sends a comparable message. Spanning three hundred years of English history, it also refers to stories of colonization and diplomatic missions. The word "Moor" appears in the very first sentence of Woolf's novel and many times throughout (with an evident intended pun on "Moor" vs. "moor"). The word "Turk" and its variants appear dozens of times, and the pivotal transformation of Orlando takes place in Constantinople (Chapter 3), where Orlando serves as "Ambassador Extraordinary". Orlando's is the world of Oriental pleasure and comfort (silk, sugar, carpets and sofas), but also of perilous adventures. Despite this obvious oversight, Jerry Brotton has told a story which is astoundingly close in spirit to Woolf's work of fiction. It is fascinating to people interested in history and culture, and especially in Elizabethan theatre. Despite a clear closure, Brotton's book opens the 
floor for further questions on both the macro- and micro-levels. On the one hand, it interrogates Britain's real versus imagined role in the world's geopolitical history, while on the other it provokes a reflection on Britons' visible and yet rarely admitted cultural connections with the Arab world.

\section{References}

Brotton, Jerry 2016. This Orient Isle: Elizabethan England and the Islamic World. London: Allen Lane.

Woolf, Virginia 1928. Orlando: A Biography. New York: Harcourt.

- 2015. Orlando. Adelaide: University of Adelaide. Publikacja na portalu eBooks@Adelaide, https://ebooks.adelaide.edu.au/w/woolf/virginia/w91o/ complete.html [02.02.2018]. 